\title{
The phenomenon of the military cemetery in Galicia
}

\author{
Olena Stasyuk \\ https://orcid.org/0000-0002-2986-6321 \\ olena.stasyuk@gmail.com \\ Department of Architecture and Conservation, «Lviv Polytechnic» National University
}

\begin{abstract}
The article analyzes the main military cemeteries found in Galicia, their types, forms, ideological affiliation and state of preservation. Preventive measures for the preservation of historic military cemeteries are proposed and the possibility of forming new ones is considered.
\end{abstract}

Key words: conservation, memorial monuments, natural stone, military cemetery

\section{Formulation of the problem}

Historic cemeteries are an integral part of the cultural landscape of each city or town, a testament to the ideology and spiritual life of its time. Military cemeteries may not be in every settlement, but they very clearly capture their time, history, and ideology - the extremely important points for the country and society.

The first military cemeteries appeared in Galicia during the First World War. That is, in the early twentieth century. The twentieth century was further marked by a series of events which replenished the number of military cemeteries. These are the Second World War and the struggle for the Ukrainian state. Regardless of the status of the cemetery, there are no objects in the absolutely perfect state in Ukraine. Each cemetery requires continuous care and ordering. Military cemeteries are additionally overlaid with an ideological component that complicates their existence.

And today we again have a war in our country. So the dead heroes. And we are already facing the problem of military cemeteries, which we will have to solve...

\section{Analysis of recent research and publications}

Interesting and writing about historical cemeteries in Ukraine began in the nineties. Mainly investigated the history of the cemetery's emergence and functioning and described the prominent people buried in these cemeteries. Mostly addressed to famous cemeteries in major cities. In Lviv, actually all cemeteries, both existing and non-existing, are described. In particular, Lviv researchers such as Pavel Grankin [Grankin 1999], Orest Dzurban [Dzurban 1999], and Chrystyna Kharchuk [Kharchuk 2011] described Ukrainian and Austrian military burials at Janiwski and Lychakiv Cemeteries. The most widely described is the Lychakiv Cemetery in Lviv, possibly because it is a historical and cultural reserve and a museum. The most complete book on the so-called Memorial of the Lviv Eagles, Polish military burial in Lychakiv is a book by Stanislaw Niceja [Niceja 2009]. From this book you can obtain all the necessary dates, historical facts and many names. An extremely voluminous and very meaningful book on the Galician military burial of the First World War is Agnieszka Partridge's book [Partridge 2005]. The book is well illustrated with both historical and contemporary photographs, which is extremely informative. And a completely new book about Yaniv Cemetery in Lviv was published in Szczecin in 
2017. Written by Barbara Patlevich and Richard Tomczyk Patliewicz [Tomczyk 2017]. The book is voluminous, versatile, contains a lot of information, a wide historical context, and of course the military burials in this cemetery are also mentioned.

\section{The purpose of the article}

The purpose is to analyze the history of emergence and formation of the military cemetery in Galicia. To show, in specific examples, the main problems of the historic cemetery preservation found on the Galicia military cemeteries. And to offer options for preventive actions to maximize the preservation of existing military cemeteries and the possibility of forming new ones.

\section{Presentation of the main material}

Let's take a look at how the dead warriors were treated in the past. In ancient Greece, mounds were heap up on the battlefields, which were both graves of the dead and symbols of victory. On the tops of mounds, stone lions were installed as a symbol of invincibility and courage. Macedonians after the victory under Herronia in $338 \mathrm{BC}$ made famous by the fact that in two identical mounds buried their dead heroes, as well as the dead Greeks. Later Alexander the Great transferred the ashes of the fallen Greeks to the Athenian Acropolis, thus forming the ethos of the hero who gave the most valuable thing to his country - his life. And also the ethos of the beaten, which was to be buried with the respect worthy of every person. In Christian Europe, dead soldiers were buried directly in the battlefields. Often, after the battle, there was a truce to clear the battlefield. Just as in ancient times fraternal graves were being prepared over which mounds of earth were poured. Distinguished and titled knights found their last rest in churches or family chapels. Ordinary warriors remained nameless.

And during the Enlightenment, when burial was restricted in churches and churchyard cemeteries, new cemeteries were built outside the city walls. The duty to care for the grave has passed from church to society and family. The changes also concerned the approach to the dead in general and the dead heroes in particular. The attitude towards soldiers' anonymity has changed. The first soldiers to be honored with a memorial tombstone were soldiers killed during the domestic wars of the French Revolution. Soldiers' monuments were erected in Lucerne and Paris. It is then that the idea of symbolic honors to the heroes emerges in the form of the tomb of an unknown soldier. In Western Europe, chapels and ossariums were built on the battlefields containing the remains of the dead. At the same time, the mound, as a form of a common grave, as well as a memorial building, remained one of the most popular forms of commemoration of the dead, according to the English researcher A. Borg (1991).

Until the First World War, no military cemeteries were created in Europe. It was the First World War that provoked the need for the establishment of military cemeteries in our latitude. During this war, soldiers died in unprecedented numbers. The war affected everyone. Newspapers wrote about it widely, eyewitnesses said. There was no family that did not suffer any losses during this war. In many countries, the need to pay tribute to the dead is ripe. Publications on ethical, aesthetic, and architectural issues related to the design of military cemeteries have emerged. In order to avoid conflicts as to how the victims should be honored, as noted in his book, A. Partridge, [Partridge 2005] the relevant military authorities were responsible for the construction and appearance of military cemeteries in France, Germany and Austria-Hungary. In each of the states, directives based on cultural traditions, respect for the dead and cultivation of memory were formulated. It is noted that every soldier should be identified, if possible, should have his nameplate, everyone has the right to receive a tombstone form which will speak about religious affiliation and military rank. The same principles applied to the burial of fallen enemies.

These noble intentions were differently implemented on the western and eastern fronts. On the western front, this was associated with incomparably greater military casualties and different approaches to the army affiliation of the dead. The ordering of battlefields, the exhumation of the dead and the construction of cemeteries began several years after the end of the war. Military cemeteries in Galicia were established during the hostilities in 1914-1918. In a situation of material crisis and general uncertainty about the further results of 
the war. It was intended that these burials would become a kind of propaganda, consolidating the peoples and societies around the Habsburg throne. They were to become tangible proof of the state's concern for those who did not return home.

The Departments of Military Graves were engaged in construction of military cemeteries In Galicia with headquarters in Krakow, Przemysl and Lviv. Lviv and Przemysl were closer to the front, respectively, experiencing greater economic difficulties and uncertainty about the military fate, which affected the scale of the objects being built. From the fall of 1914 Lviv was occupied by the Rossian army, which was in no hurry to organize the battlefields. The sum of the various reasons is arranged in such a way that the cemeteries built by the Krakow Departments of Military Graves are the only artistically compact and preserved in original form complex of military graves from all Galician regions.

The phenomenon of Galician military burials of World War I is the fact that in one cemetery the remains of soldiers of the enemy Rossian army were to be buried near the bodies of the heroes. It should be emphasized that such a thoughtful burial action at one cemetery of the bodies of winners and losers had no example in the past and has never happened again. This is the only example of deep humanism in the field of military cemeteries. In modern Poland, these cemeteries are monuments and are provided with protection and care. An example is the cemetery in Luzhna Pustka of the Malopolske Voievodstvo in Poland (Fig. 1). In 2016, the cemetery was awarded the European Heritage Label. It has been completely restored as a site and is one of the largest military cemeteries of the First World War in western Galicia.

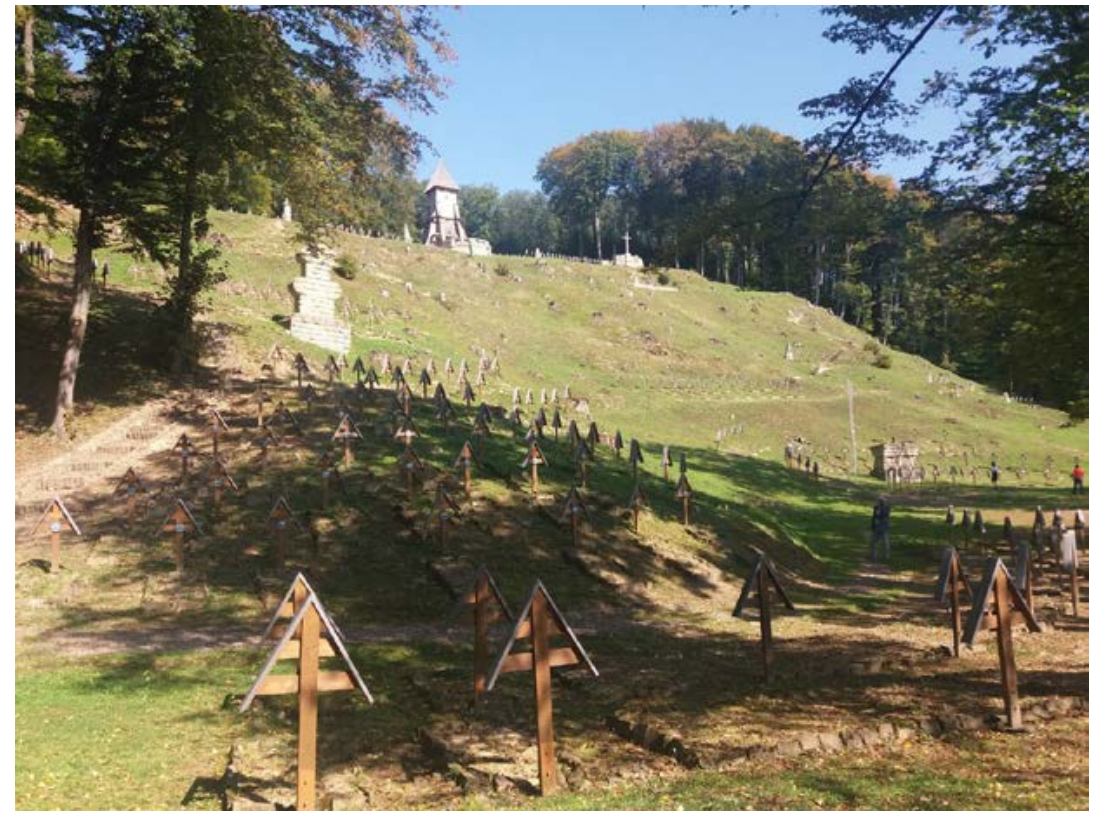

Fig. 1. The military cemetery in Luzhna Pustka of the Malopolske Voievodstvo in Poland

It should be noted, however, that this example of deep humanism only concerned Christians. In the armies that fought in World War I were Muslims and Jews. Such fallen soldiers with full respect were buried in separate cemeteries. For the people of that time, certain religious requirements were important and the state respected and considered them. That is why in the territory of modern Ukraine in Galicia we have several Muslim cemeteries of the First World War. For example cemetery in the village of Lopushnia, Rogatyn district, Ivano-Frankivsk region (Fig. 2).

After the First World War, borders and states changed. In our territory there was a short Ukrainian - Polish war, which ended in the defeat of Ukraine. An independent Polish state rebelled. Galicia became part of it. The military cemeteries of World War I remain in Galicia as they were built by the Austrian state. No one is destroying them, but no one is building new ones, like in Western Europe. The Polish state in Lviv builds a pantheon on the Lychakiv Cemetery in the so-called «Lviv Eagles» for Polish soldiers who died for Poland's independence in the Polish-Ukrainian war. The principles of humanism demonstrated on these lands by the Austrian state 
have been rejected and denied. The Polish authorities do not allow the building of a military cemetery for the Ukrainians who died in the war. And, of course, there is not even a speech to bury opponents in one cemetery.

The Second World War is breaking out in Europe very quickly. The front passes through the Galicia several times. After the war, borders and states change again. Galicia was split between the Soviet Union, which got central and eastern Galicia, and Socialist Poland (PRL), which got Western Galicia. The Soviet Union was an extremely ideological state. All humanistic principles and ideas were ignored, did not work. The cult of the Soviet army and the Soviet soldier of the liberator and the victor were introduced everywhere. The idea of a monument to an unknown soldier, which was widely spread throughout the Soviet state, was taken up. Each settlement had to have an obelisk, a memorial sign, an eternal fire, and so on, which should have glorified the Soviet army.

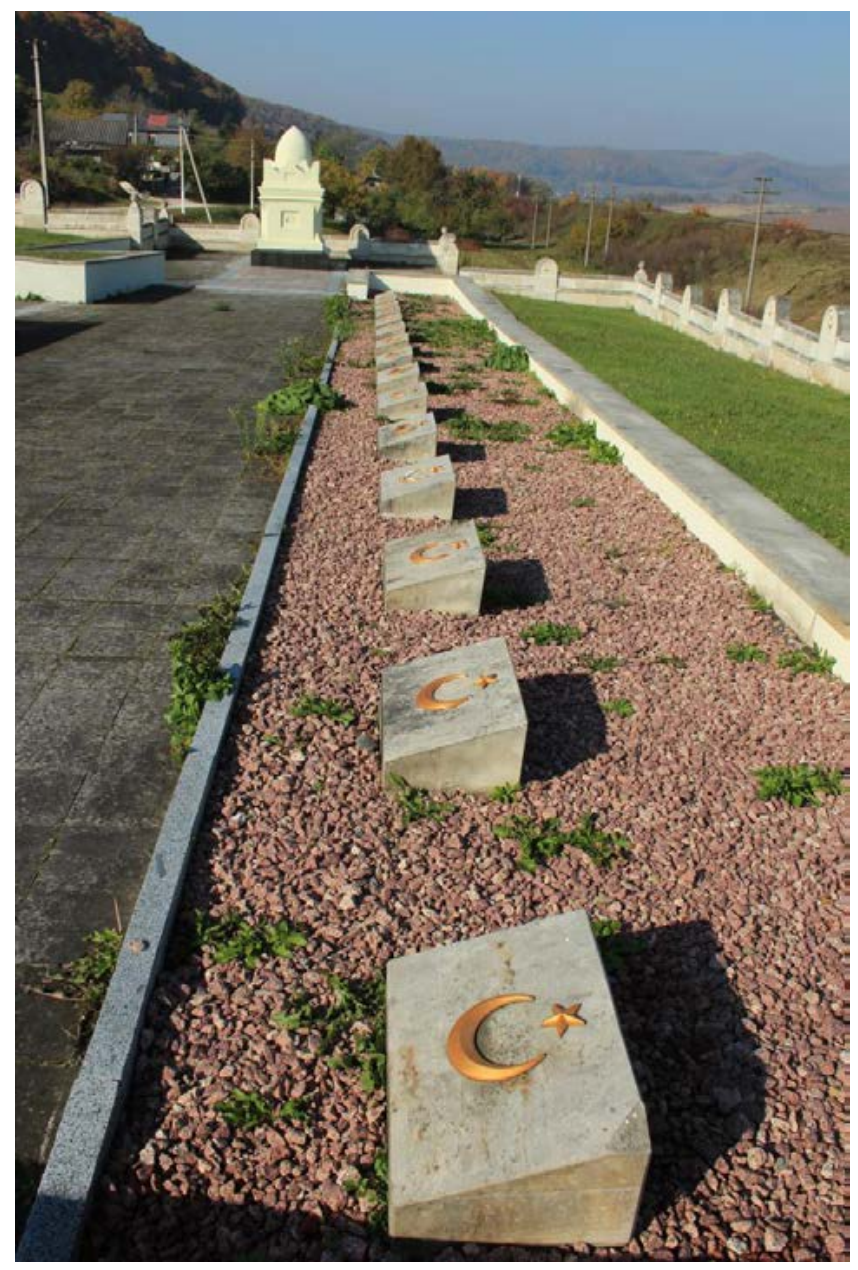

Fig. 2. The military cemetery in the village of Lopushnia, Rogatyn district, Ivano-Frankivsk region

In 1915, during the occupation of Lviv by Russian troops, a Russian military cemetery and park was erected on Mount Lychakivska Street. After the end of World War II, the cemetery was rebuilt and the soldiers of the Soviet army reburied there. On February 23, 1948, the solemn foundation of the Soviet Army Memorial was held here, and on February 23, 1958, the Memorial Hall of the Hill of Glory was opened. I must say that such memorials were extremely monumental, very ideological and artistically very skillfully and qualitatively executed. At the same time the ideological symbols of the previous states and peoples who inhabited these lands were destroyed. In 1951, the Eagle Memorial in Lviv was destroyed. In 1956 the central tombstone of the Tomb of the Unknown Soldier was taken to Poland. In 1971, the graves and the colonnade were destroyed by tanks and construction equipment. Military burials of World War I in Lviv were also located at the Yaniv Cemetery. In particular, a military memorial to UGA shooters, which was destroyed by the Soviet authorities in 1971 by bulldozers. 
After Ukraine gained independence in 1991, events began to reverse. In 1998 a construction of the memorial for the soldiers of the Ukrainian Galician Army was started at the Lychakiv Cemetery, and in 2005 it was solemnly opened (Fig. 3). In 1997-1999, a memorial to the UGA shooters was restored at Yaniv Cemetery in Lviv. In 1990, the restoration of the Memorial of the Lviv Eagles at Lychakiv Cemetery began (Fig. 4). At many cemeteries in Galicia, the remains of UGA shooters and other military formations that fought for the statehood and independence of Ukraine were found. Communion forces set up memorial crosses with tables showing their status as fallen soldiers and heroes, and that their sacrifice was not in vain.

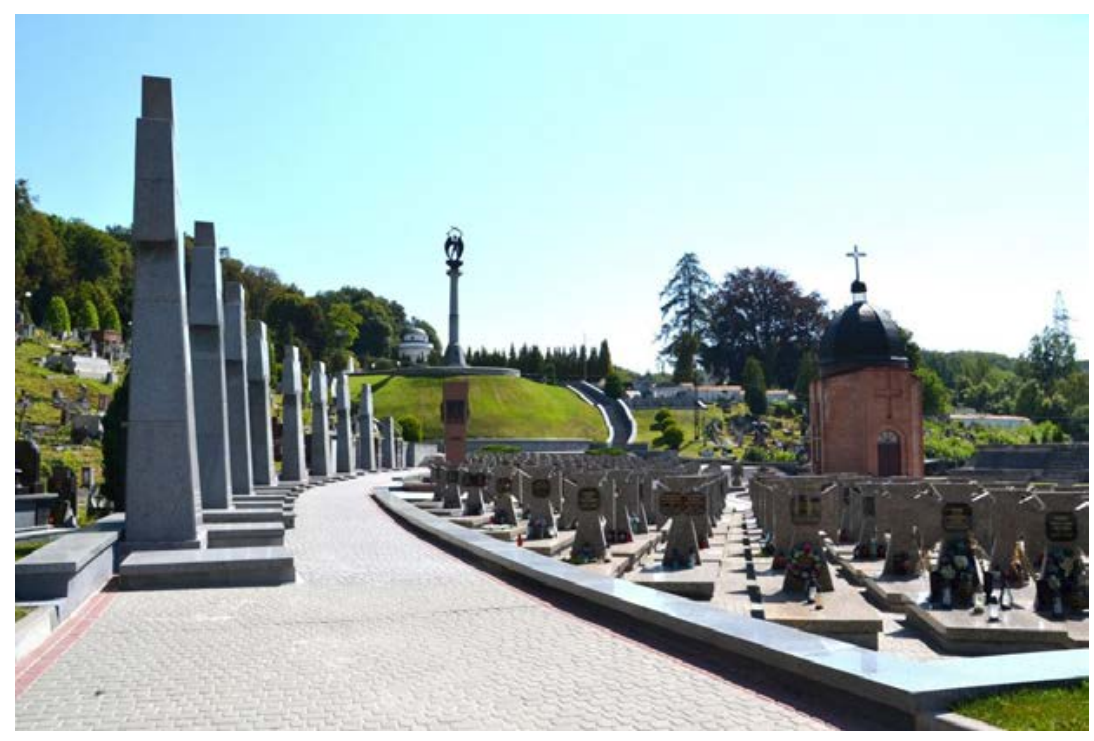

Fig. 3. Memorial for the soldiers of the Ukrainian Galician Army at the Lychakiv Cemetery

In 2014, in the independent Ukraine, the execution of the celestial hundred took place. The fallen heroes returned to their homes. In Lviv, they are buried at the Memorial to the soldiers of the Ukrainian Galician Army at the Lychakiv Cemetery. Other cities also hold memorials to the victims. Very soon, after the shooting of the celestial hundred, the war began. It is still going on. And the expense of the losses we incur in this war does not stop. The question of the military cemetery to the heroes of the modern war remains open.

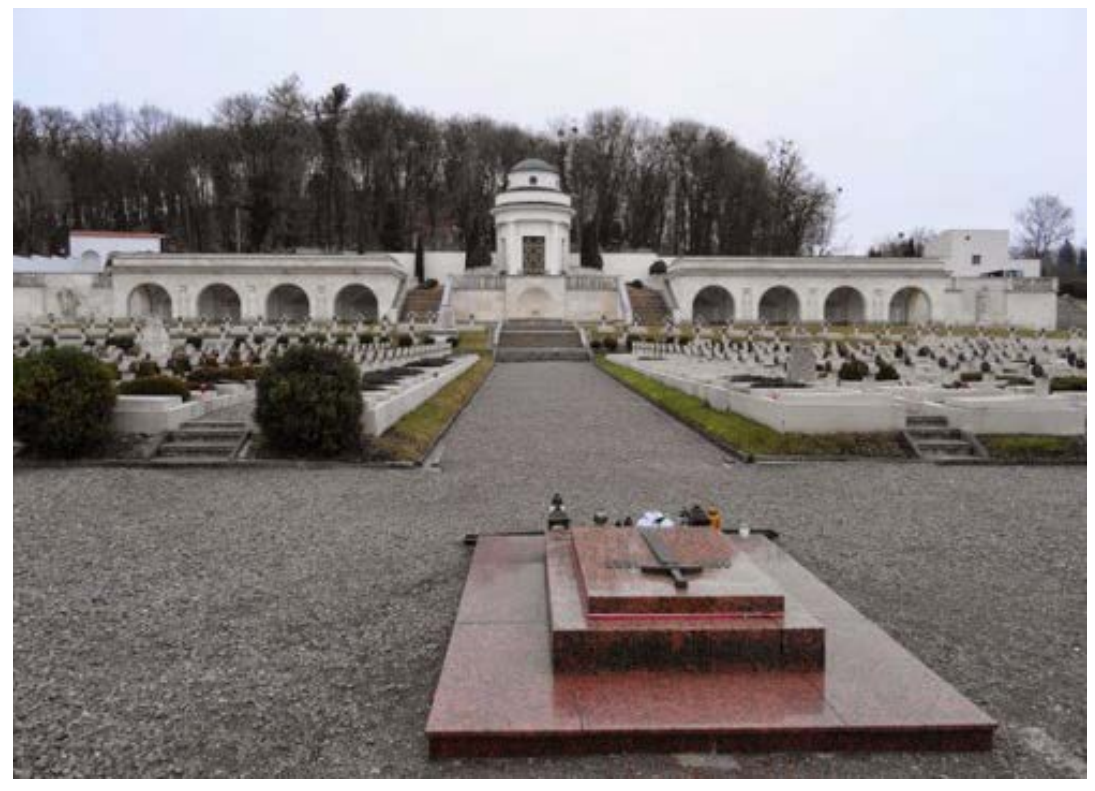

Fig. 4. The Memorial of the Lviv Eagles at Lychakiv Cemetery 


\section{Conclusions}

Military cemeteries are a very important and very vivid part of the people, society and the state memory. In fact, they were designed to preserve the memory of the fallen heroes, as well as their actions. The history of military cemeteries goes back a little over a hundred years. It's not so much. For the history, it's not just a child's age, it's a baby. It's three generations and the fourth, which has already emerged but is just growing up. During this time, two world wars have swept across Galicia the land where we live in today and four states have changed. It's a lot. States with different languages, different ideologies, philosophy and purpose. Each of these states builds its own history, upheld its ideology and tried to emphasize its victories and suppress defeats. And these victories and defeats were very clearly visible in the military pantheon.

So the military cemeteries on this land are running out. During the time of the Ukrainian state, the destroyed military cemeteries were rebuilt as far as possible. Responsibly, I declare that the Ukrainian state does not destroy cemeteries the military cemeteries as well. No matter what ideology they are filled with.

As for the current condition of the military cemeteries, it can be described as satisfactory. These cemeteries require continuous care and custody. They are destroyed by natural factors. Consideration may be given to these sites for monument status. It is absolutely necessary to carry out continuous educational activities for public awareness the importance and value of such objects.

As for the creation of new military cemeteries, it is possible that this issue should be postponed until the end of the war. Give time to relive and reflect on events, understand what is most important and what you want to remember, save forever. European experience has shown that this is the way to achieve a very high quality and interesting result (such as the Redipulla Pantheon in Italy or the memorial on the battlefield in Verdun France).

\section{References}

[1] Hrankin, P., 1999. From the history of the military cemeteries of Lviv (1914 -1918), The Galician Gate, 5-6 (53-54) pp. 14-15.

[2] Dziuban, O., 1999. Shooters necropolis of Lviv. Halytska Brama, 5-6 (53-54) pp. 10-12.

[3] Kharchuk, K., 1999. The Austrian military cemetery and the burial of Ukrainian shooters at Lychakiv. Halytska Brama, 5-6 (53-54), pp. 20-23.

[4] Kharchuk, K., 2011. Military burials at Yaniv Cemetery in Lviv, Military History Kyiv, 3, pp. 46-57.

[5] Borg, A., 1991. War Monuments, London: Leo Cooper.

[6] Patliewicz, B., Tomczyk R. 2017. Janowski Cemetery in Lviv. Polish National Heritage Szczecin: Uniwersytet Szczeciński.

[7] Partridge, A., 2005. Open the gates of memory. War cemeteries from 1914-1918 in Lesser Poland, Kraków: Lettra-Graphic.

[8] Niceja, S., 2009. Lviv Eaglets act and legend, Warsaw: Wydawnictwo Iskry. 